\title{
Is Intensive Farming Ethically Acceptable?
}

\author{
Michiel Korthals \\ Professor of Applied Philosophy, Wageningen University, Free University, Netherlands \\ Email: michielkorthals@gmail.com
}

\begin{abstract}
Intensive farming in which high chemical inputs deliver high outputs [23], is the object of severe criticism [29]. In this article firstly an ethical framework is presented to ethically evaluate intensive high input farming. The framework consists of six ethical criteria according to which farming styles or regimes can be evaluated. The six criteria are Can the farming and food style reduce hunger, poverty and malnutrition? Is it sustainable? Is it animal welfare friendly? Is it fair and just to farmers and others? Does it stimulate rural liveability? Is it consumer friendly: does it decrease the gap between production and consumption and does it connect positively with rural and urban areas? Secondly, in applying these criteria I evaluate the current dominant intensive farming, by analyzing prominent texts and data from international organizations. Finally, I will argue that the balanced fulfilment of the six ethical criteria comprise something like a fair representation of food and farming styles in science, governments and markets, that culminates in food democracy where gaps between consumers and producers are mitigated, bridged or deconstructed.
\end{abstract}

Keywords: Intensive agriculture; ethical evaluation; sustainability; consumer friendly; agro food democracy.

\section{Introduction: Ethical Considerations about Agriculture and Food}

In accordance with a lot of ethical literature about farming, I will here present an ethical framework, which consists of six ethical criteria according to which food and farming styles can be evaluated. The first aim of agriculture is to tackle hunger, malnutrition and poverty. The second should be: to reduce as much as possible the environmental footprint, by being sustainable in the sense of the Brundtland definition: to leave the next generation as many possibilities as the current one. Thirdly, in using animals, it should take of their wellbeing and integrity. Fourth, farming should give farmers and other food professionals a respectful living. As a consequence, fifth, it should take of the landscape and rural liveability. Sixthly, it should take into account consumers (citizens) concerns about transparency, animal welfare, and justice. The six criteria can be formulated in six questions:

Can the farming and food style reduce hunger, poverty and malnutrition? Is it sustainable? Is it animal welfare friendly? Is it fair and just to farmers and others? [1] Does it stimulate rural liveability? Is it consumer friendly: does it decrease the gap between production and consumption and does it connect positively with rural and urban areas? [2] The first five criteria are quite in agreement with what many people will endorse, and are formulated in for example the Five Freedoms of the Bramdell Report [30]. The last one is an implication of the consideration that food is an essential aspect of human identities. It needs some explication here. Why should one strive for decreasing the gap between production and consumption, although many involved in the food sector try to increase the gap? Why is the resulting alienation of consumers with food a serious ethical problem?

\section{Identity Achieving Functions of the Meal}

Consumers are not simply buyers, and producers not simply suppliers and food is not a simple commodity. Even in modern and postmodern times, despite of the gap between production and consumption, consumers are moral and social actors that anticipate and consider the interests of others, which often culminate in boycotts, buycotts and other protests. [3] Consumers are constantly in need of deliberation about what best to buy and eat, about which information to take serious and how to connect it with daily life plays an important role. In discussing food preferences during a meal, the whole gamma: prize for others, sustainability, animal friendliness, and other values can be raised. I call 
this the information-exchange function of having a meal together. As a matter of fact, the exchange has also a place outside having a meal, in other public or private places.

But a meal is more than deliberation. Because food has identity constructive characteristics, peoples are emotionally and attached to the food they eat (and, as I will argue, attached to the people they eat with). I will call this the emotional function of food, which is connected with the personal and social identity function of food. [4] Directly connected with the emotional function, is the bodily function. Simply tasting food illicit all the senses, and energizers all bodily functions. Preparing a meal for others is also a quest for what your guests and you really like in for instance a cabbage dish or a whole-grain bread. This is the discovery function of food. It is a simple way of getting the perspective of the others and of maintaining and intensifying relationships; having a meal with others has a social identity achieving function.

Food can even be used to stretch these identities and at least to desensitize the often tense relations with strangers or with people that are seen as enemies [5] This also implies that the personal relations people have with food and with the people they share the food with are essential for daily life. They can never be totally substituted by large scale companies. The large scale companies like Nestle, Unilever and Kraft produce food items operating everywhere in an nowhere world, not accessible to the consumers Formal, large scale, anonymous organizations steered by money and power can never replace the personal and social identity achieving dimensions of living with food. Experiences of meaningfulness in what one is eating is possible on the basis of a social shared or self-made meal, or one where one has played an organizing role. The call of some scientists to get rid of the idea of authentic or personalized food and home cooking and to be satisfied with standardized food items in packages, pills, bottles and bags goes against the grain of every psychology of food and daily life [6]. Besides the fact that these identity achieving functions of food contribute to living a good life, humans need a certain amount of personal trust: not everything they buy, cook or prepare for a meal and eat, can come from large companies that are processing food anonymously at a distance [6].

Trust in persons performing in the context in which food is made, has its anchor point in daily, informal contacts. Trusting companies and the processes and persons functioning in the anonymous and distal food chains requires complex achievement that is conditioned by personal encounters. First, you have to transpone the official claims of trust, done by certification, branding and marketing, and translate them into your own belief system. Secondly, people need narratives to understand and place the companies and their food items in their own world, in their own range of accepted and esteemed practices. The gap between producers and consumers makes it very difficult to decipher the real messages of food industry; decoding is a necessity.

The daily routine of eating (in combination with the estrangement of consumers from their food) often lures us into oblivion of its values; it induces us to frame eating as downing, as grazing and nothing else, and the food environment with its urge to have as many eating moments as possible strengthens us in that feeling. Often it seems as if eating is not about the process from farm to table but from lab to esophagus. Daily routine of preparing a meal can feel to be boring, and this makes it possible to feel relieved by the possibility to buy readymade, standardized meals made by some anonymous machinery. It is indeed sometimes difficult to do something with pleasure that repeats itself every day. However, spending more time, not less, in acquiring tasty things from engaged people (craftsmen and craftswomen) and in finding out new recipes can make pressures of daily life durable, even and transform them into events of pleasure. Co-creation of farmers and consumers also has this effect. Art and new technologies, with its deregulating and world disclosing dimensions can have also the effect that gives one once in a while the feeling that cooking is a discovery, a quest for the good and tasty [36].

Nevertheless, it is not necessary to be continuously busy with food [7]. Routines and habits on the basis of experiences and trust that guarantee sustainable and pleasurable meals are therefore also important [8].

Being busy with food has also an important political value for the implementation of two very important Human Rights that until now are not everywhere respected, the right to know and the right to adequate food. Human Rights Law has been used to stipulate that Food is a Human Right, which shall be protected by the legal instruments of the UN system [34]. For consumers this implies the right to safety; the right to be informed; the right to choose, the right to be heard; the right to representation; and the right to adequate and legal protection. The Right to Food got in 1966 its full meaning in the International Covenant on Economic, Social and Cultural Rights (article 11), as the right to available, 
accessible and adequate food. Adequate means 'culturally acceptable'. These rights are incorporated into the EU consumer policy program. After the Rio Convention (1992), in which the overall importance of sustainable production was agreed upon by most nations, and the formation of the European single market, the ethical consumer and diverse consumer concerns came to prominence. As is stated in General Food Law (178/2002/EC), which defines producer (food chain) responsibility, active consumers are to be informed according to their rights [31]. These rights together form the core of food sovereignty. Food sovereignty allows greater accountability to ensure implementation and addresses the unique food needs of persons and communities. When food chains are short, local orientation allows easier and better control over food production, and one can quickly act if the production doesn't meet the preferences and if certain products produce health hazards or go against fundamental insights of sustainability.

Human life is embodied and bodily life, and therefore also the relationship with agricultural nature must be nurtured and exercised, especially through farming, gardening or cooking. Local attention and practices of farming, gardening and preparing food are an absolute requirement for understanding what nature can offer. Understanding what nature offers us means that one can discern between the edible for body and mind and the not-edible, and between possibilities and impossibilities of natural resources, including our own.

\section{Current Agro-Food Systems, Food from Nowhere versus Food from Somewhere}

Globally current agro food sector consists mainly of two agro-food regimes, intensive bio-industry (IBI) that delivers food from nowhere and agro-ecological food production (AECO), with low inputs and food from somewhere. In the first, agricultural production is treated as an industry like others, and is depended on high (chemicals, GM seeds) inputs to get high outputs and international corporations. This regime reduces as much as possible the number of people working on the fields; this reduction has now in the Netherlands reached the incredible low percentage of 1 percent of professional workers. While some food in the prewar period travelled significant distances, nearly all food in the Western world today is consumed a long way from its site of production [9]. Food items travel through many channels and links all over the world till they reach finally as an edible product the plate on the table. Although this alienation between producers and consumers is the endpoint of a long history [32], its acceleration is the result of a strategy of the contemporary dominant farming and food style [33, p. 66].

The second regime focuses on local food production, and strives for increasing production by using eco system services and low inputs and emphasizes short chains and crafts (practices). The food comes from somewhere, as in the 100 miles diet. This regime covers the total context of food production and consumption: livelihood, landscape, and good life (one of its names is therefore Community Supported Agriculture, CSA, and another one Conservation Agriculture). The first food regime is dominant in the Western world, so I will concentrate here on that one.

\section{Intensive Bio-Industry (IBI)}

The intensive agro food regime is heavily focused on increasing production by market parties. This by no way factual, but very normative message, has become the basis of the current regime of agricultural intensification of production. It treats food and agricultural products as commodities, not different from cars and computers, with one remarkable difference, that nowadays consumers are alienated from the production process. Consumers don't know what and how to eat. Comparative (economic) advantage nothing else determines what, where and by whom food is produced [10]. Producers are entangled in an economic treadmill, try to prevent the diminishment of their profit margins and go continuously for the cheapest.

Producing food is since the Second World War seen by many as an activity that can best be performed by something like IBI. In this industry sector (like that one of electronic devices and cars) ingredients for edible food items come from all over the world, and the final product should be as readyto-use as possible so the consumer can put it in his or her mouth without any doing. The food comes from everywhere or better from nowhere, because nobody oversees to chains and knows anymore where exactly the ingredients come from. Farm and table are not connected; distances can be enormously and 
ingredients are changed into nearly unrecognizable substances, like 'pink slime' [33]. This is particularly the case with edible items that are composed of bulk ingredients like maize, wheat or rice. These bulk products are shipped from everywhere, mixed, shipped again, partly processed or packed in some location, and partly in another location.

This type of framing of agriculture, farmers, food and consumers is to the advantage of many large companies and shareholders. This approach is also called the 'productionist paradigm' of agriculture; its main features are its high inputs and high outputs [12]. Probably, it can produce food for even more than eight billion in 2050 but the cost will be enormous. The Dutch agriculture is a good example of intensive farming; less than $2 \%$ of the labor force is working in agriculture and its yearly use of chemicals is one of the highest in the world per hectare.

This regime has produced remarkable results, and inspired lots of scientific achievements, like the insights of food sciences about the importance of nutrients and ways to conserve food safely. Although this paradigm can be proud of its enormous success to feed the world, it also produces huge problems, which make it according to many unsustainable and socially not fair [42]. One of the problems this system directly is confronted with has to do with the fact that the sources of food are natural items. This means that they run the risk of being contaminated, polluted and deteriorated, and are therefore object of food security measures from farm to table. Diseases and in general the safety of food due to the long distances (in space and time) are a concern for the more responsible partners due to often unclear chains that somewhere come together to finalize into an edible item. Disease control and surveillance of safety of food are often the main ethical issues that are addressed in this regime to reduce food borne pathogens and pesticide residues. Industry boasts about the huge efforts of sound scientific testing and transparency. Costs to clean up and to establish traceability and food safety systems (such as HCCAP and GRAS, generally recognized as safe) are increasing, next to the external costs of for instance antibiotics [6] [37].

In judging agro-food regimes according to the ethical criteria, it turns out that the current dominant food system of intensification and quantification is suffering from unresolvable problems, from environmental impacts, to health problems like obesity, to endemic fraud and to deactivating citizen consumers. It does not fulfill the six ethical criteria earlier mentioned. Can the style reduce hunger, poverty and malnutrition? Is it sustainable? Is it animal welfare friendly? Is it fair and just to farmers and others? Does it stimulate rural liveability? Is it consumer friendly: does it increase or decrease the gap between production and consumption and does it connect positively with urban areas?

First, although there is enough food to feed eight billion people, more than one billion people on earth suffer from hunger and even more from malnutrition (FAO 2010). The current system is not able to feed everyone. This is often an issue of people not having enough to buy food (no entitlements, no jobs, not in possession of their own plots anymore, etc.). Nevertheless, the increase of population and of demand and degradation of arable land make the problem of food security for the next decades the more urgent. Harvest catastrophes, more mouths to feed, and speculation will cause the rise of prices. Moreover the increase in demand of animal products and, therefore, crops for animal feed and of biofuels (which has as a side effect a higher pressure on food crops [29] will also increase prices. Rising food prices play a role in food riots in countries in which people have to spend a lot of their household budget on food [40] [41] [43] [12] [35]. But a big blow to this regime will be the depletion of mineral oil reserves, the main resource of the chemicals and fuels used; in the coming twenty years shortages will become more radical and only the rich can afford to buy these products.

Secondly, the current food and agricultural system is not sustainable. The current system of intensification depletes finite resources in a high speed. It is responsible for degradation of the soil by over intensification and for deforestation (in particular in Latin America and Southeast Asia). It pollutes water and soil by manure and chemicals [13]. Take the use of herbicides as an example, although many believe that GM crops enable using less pesticides, now, after several years, the Darwinian struggle between pests and humans result in higher resistances among pests and GM crops need the last years even more chemicals than in the nineties with conventional crops, as this USDA and Food and Water Watch chart shows (Figure 1). As said, IBI is heavily dependent upon fossil fuels. Moreover, they increase global warming [54]. Crops yield will due to soaring prices of oil diminish in approximately 10 years and after another ten years the resource is depleted and chemical pesticides have to be produced according to another method or cannot be produced anymore [12]. 


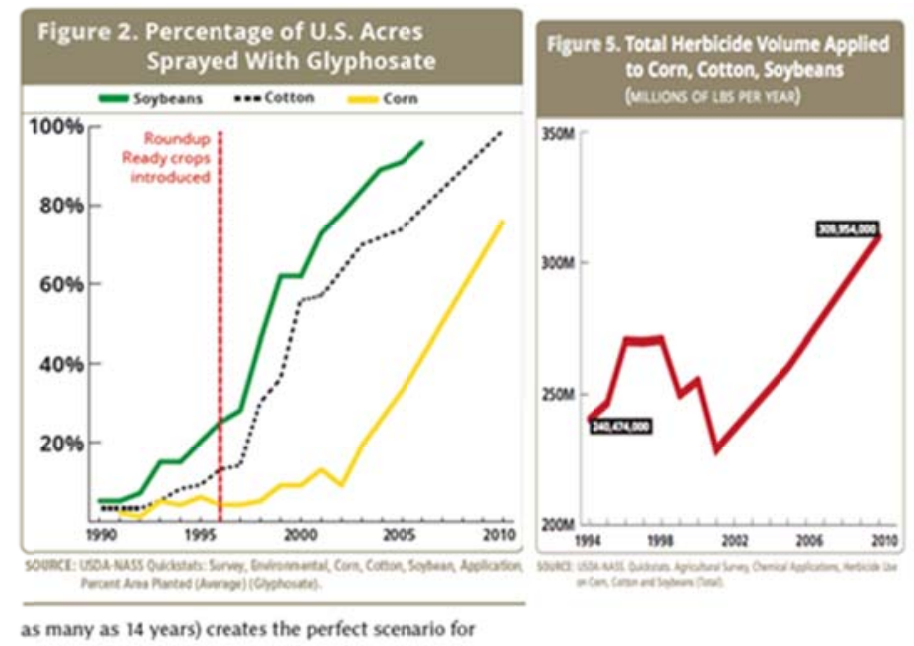

Figure 1. Increase of use of herbicides to corn, soybeans, cotton (the dip in use in the first years of use of GM crops and the huge increase afterwards is nicely illustrated)

The antibiotic resistance in humans is increasing by abuse of antibiotics in intensive animal factories (f. i. people involved in pig farming have their own entrance gate in Dutch hospitals). Unbridled fishery and aquaculture empty the seas quickly. The use of pesticides has huge costs according to Pimentel [53], among others the deaths of 200.000 people globally due to overuse. All these material and immaterial costs are externalized and the burden is put on the shoulders of taxpayers and nature [43]. Consider the question of consumption of animals as food, though it constitutes only one of many effects of agriculture as a whole. Animal husbandry contributes disproportionally to climate change, approximately $18 \%$ due to its methane emissions (Steinfeld 2006). Global meat consumption has been estimated at 228 million tons (FAO 2009) and is expected to double by 2050 to $465 \mathrm{mt}$. Given that livestock currently account for $40 \%$ of global grain production by 2050 livestock will be consuming food that could feed 4 billion people directly [13] [14] Eating meat is not caused by Intensive Bio-industry but this regime has a big stake in letting people eat meat and will not implement policies out of free will that reduce meat eating.

This regime reduces agro biodiversity in a fast tempo. Only a few races of wheat, corn, soy and rice are used. The standardized and uniform crops and animals destroy the basis of a healthy agro system, because disposing over a lot of different variants of one species functions as a kind of safety system and reduces the risks of losing the battle with pests and abiotic stresses [15]. Standardization is a consequence of the economic trend towards monopolies of seed production, see criteria four. Some of the proponents like Borlaug [23] stick to the idea that intensification of agriculture sets free more wild nature. This idea has been proven false by social science research. In countries where intensification takes place, like Brasilia, nature loses more and more due to the treadmill in which farmers feel pressed to acquire more land to safeguard their investments (Ewers et al 2009). Moreover, the use of chemicals on agricultural areas in this regime has deteriorating consequences for the level of biodiversity in neighboring natural areas (Stevens et al 2004; Van Swaay 2008).

Thirdly, human use of animals in intense systems raises ethical issues; the animals, not having a voice, endure pain and suffering by being confined in very small pens, inhumane forms of slaughtering, and degrading treatment as mere objects. Approximately 55 billion land animals are slaughtered every year. The breeding industry boasts about an increase per annum of at least one egg, more meat and milk from chickens [16], pigs, and cows. In the western countries, there is a growing concern and sensibility for the abuse of animals, which gives rise to strong NGOs and sometimes governmental measures, and increasing intensification will not make these concerns disappear [30].

Fourthly, in terms of economic impacts, IBI with its food and agro-monopolies, being an important part of the global trend of the establishment of monopolies, does not treat farmers and consumers fair. Large, private companies determine more and more what food is produced, where, under what conditions. What people eat is determined by a very few top managers in the world. Concentration of food production in fewer hands is often pictured by the famous Supply Chain Funnel or glass hour of 
Grievink [17]; others have also documented the trend of control in fewer hands. "These companies and monopolistic networks operating on a global free market are more powerful than individual states; large shareholders speculate with food and make the food trade a casino, with all the risks for food security and price stability [39, p. 29]. As Larry Busch [6] argues:

'In their quest to limit the power of the nation-state proponents of neoliberallism worked hard for more than a half century to reduce direct state regulation of markets, create international institutions that limit state power, and whenever possible employ markets as distributive systems. In so doing, they have opened the door to the creation of private governance systems such as those described here' $[6$, 346].

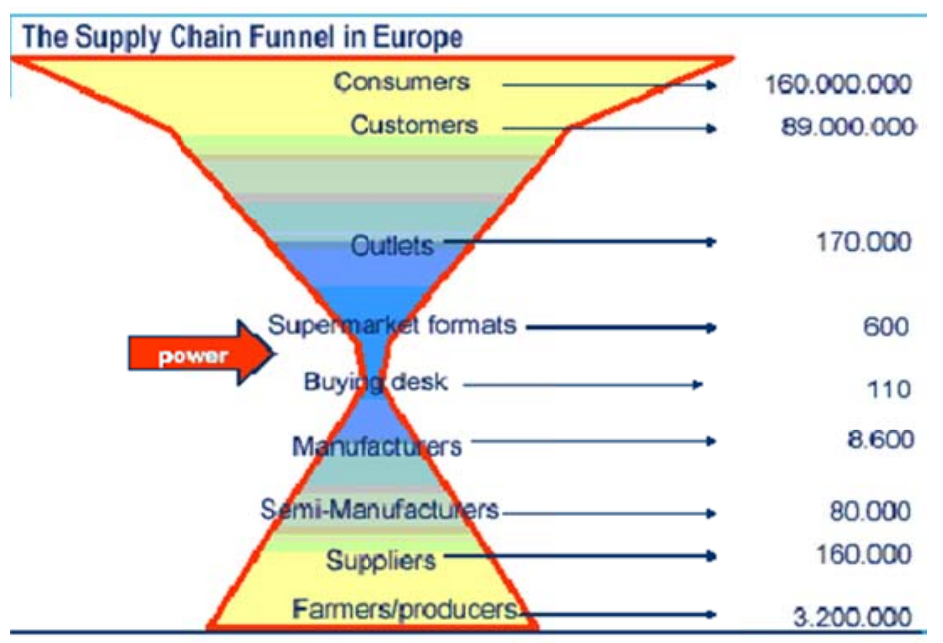

Figure 2. Supply Chain Funnel in 2009; in 2013: 400 supermarkets; 70 buying; desks [17]

For many, the ultimate commodification of food production has unacceptable consequences for food and for small farmers. First, this commodification of food has unfair distributive consequences according the Rawlsian principle. It increases the gap between rich and poor by suppressing poor farmers and even chasing them from their land in exchange for large plantations that are managedl mechanically. Prices show huge fluctuations (GM seed for cotton is now three to four times more expensive than during the introduction), which makes it difficult for a farmer producing for the market to plan ahead. Moreover, high prices, for the most part, do not translate into high revenues for farmers, and low prices paid to farmers do not necessarily mean low prices for consumers. Often, the worst situattion happens: the few rich farmers get the highest prices, and simultaneously for consumers in poor areas, living in towns, the prices soar. The large farmers get richer, the smaller get poorer, and in the end, the small farmers have to give up their land and become jobless slum inhabitants. The economic treadmill [50] displaces small farmers, and makes them potential victims of urban poverty and unemployment. Unemployed farmers move to slums, without a chance for a decent job and are trapped in the urbanization trap (World Bank 2013).The price fluctuations also stir up speculation which often has disastrous consequences. Moreover, the policy of vertical integration, which means that stronger companies higher up in the chain (for example manufacturers like ADM or retailers Ahold and Nestle) determine what farmers have to produce, makes farmers still more dependent (James 2013). The current patenting system contributes to this increasing the gap between rich and poor, thereby producing inherently instable social relations and enhancing food insecurity. Moreover, according to many, the extension of intellectual property rights over organisms both hinders bottom-up innovation and stimulates the growing gap between rich and poor countries. While in the West the consumer class thrives, great disparities remain. Worldwatch notices: 'The 12 percent of the world's population that lives in North America and Western Europe accounts for 60 percent of private consumption spending, while the one-third living in South Asia and sub-Saharan Africa accounts for only 3.2 percent.'[18] Medicin sans Frontieres speaks about the ten ninety gap with respect to medicines and the resources used for them [20], and the same gap can be identified when one looks at agricultural research investments: only 6 per cent of privately funded agricultural research is focused on developing country agriculture. [20] This gap between research 
investments in crops for the North and for the poor South is also the case with respect to conventional and organic farming [21].

A second criticism of commodification concerns the fast reduction of labor in agriculture and time spent for cooking and eating, which implies outsourcing skills and capacities to maybe $1 \%$ of the labor force and large processing industries (as is the case in one of the most intensive agricultural countries, the Netherlands, the Lance Armstrong of agro-food). These capacities are essential to bring humans into contact with nature and the world. This lack of engagement with the living environment is a common trait of radical commodification: it allows only passive consumption (Sunder 2012). A consequence is the enormous waste of food, because producers and consumers don't respect food. Economic policies premised on free global markets are held in some ethical systems to run the risk that commodification of nature becomes a universal dogma [21]. When, for example, ecosystem services, like fresh water or carbon sequestration are monetized, this imposes, first, that the biosphere is sliced into components or itemized, and then these items get a price tag. Rich groups or nations can afford these prizes and, therefore, deplete these services. The ensuing disaggregating of nature's functions in the end destroys them [57]. A last socioeconomic issue is the drive of powerful companies and nations to buy arable land from governments, often neglecting informal local rights, with the consequence that poor farmers have to live elsewhere. 'Land grabbing' as this is called by critics, implies producing biofuel or animal feed for livestock (farmlandgrab.org; [58]).

Another concern connected with the still growing importance of monopolies in the food sector is the confusing relation between private and public in science and technologies blurring private and public goods. The Dutch Top sector policy encourages the connection of science, be it natural and social sciences or the humanities, with large companies and industry and is a barrier for the essential trait of science to be critical, doing extra ordinary things and to share ideas, theories and data with peers. Private companies are doing their best to balance their private interests with general social rules, but they are not interested in funding and participating in research that goes against the grain, that presupposes that there are no trade secrets and for which educating and teaching people that are talented, and not that have money, are vital in developing new ideas.

The application of the fifth ethical criterion encounters the consequences of the commodification of food. When farmers are evicted from their land, they leave behind rural areas that are increasingly toxic, monotonous and populated by a small army of often immigrants or uprooted people [3]. The economic treadmill [50] reduces chances for flourishing rural areas, and produces inherent instable social relations and food insecurity [52]. The proponents of this regime defend it often by remarking that it is able to engage poorer areas in the world market with the consequence of higher prices, higher profits and higher food supply. The preference for local food would according to Standage be 'tantamount to denying them (Southern farmers) the opportunity of economic development' [55, p. 75]. However, the common idea that agricultural investments in poor countries will give those countries an economic boost is a fairy tale. For example, according to estimates of SEO, 'the gross margin of the supermarket on red pepper can be up to $63 \%$ of consumers euros, the rest will go to wholesalers (7\%), grower (24\%) and VAT (6\%).' (http://www.seo.nl/en/page/article/van-teelt-tot-schap/). Another example: 'for Pangasius Western consumers pay approximately $10 \$$ per kilo, the farmer in Vietnam gets $1 \$$, and has after deduction of costs less than $0.1 \$$ in his hands' [56]. Profit margins of Western companies on fresh products from the South are high, and the profits are not channeled back to the South.

Six, IBI increases the gap between production and consumption in several ways. One way covers the lack of trustworthy methods to handle food risks, zoonosis, or technological risks developing with new biotechnologies (like nanotechnology or genetic modification). Food safety is a problem for many, although probably behind the fear of contamination, residues, and pollution lurks the often unspoken distrust of the public toward a food system that exercises immense but not controllable power. Governments, pretending to be guardians of risk management, are often not trusted. In the Netherlands in 2014 the Onderzoeksraad voor de Veiligheid published the report Risico's in de vleesketen (Risk in the meat chain) with a devastating verdict on the current safety system in the meat sector, more directed to free trade than to the safety of products. The concerns about safety, other food risks and problems can often not be silenced by claims of scientific testing and transparency because many doubt that the public-private partnerships produce objective information and impartial testing. Moreover, these other concerns are often inspired by different worldviews than the one underlying these claims. Critical consumers put in doubt the values and connected worldview that are underlying this intensive 
regime, such as convenience, efficiency in producing the largest volume of edible things and uniformity [33, p 67, reference 36]

Consumers feel left in the dark due to what they see as the distorted relationship between science, technology and business. They fear that technologists go too far in denaturalizing food items and in the use of recombinant DNA technology in transforming agricultural plants and animals [49]. Science-based health claims connected with (functional) foods are encountered with criticisms (and they change every year). Scientists bring in the so-called advantages of lower farm cost determined by genetic modification, but there are no advantages for consumers. Moreover consumers are concerned due to arguments about environmental costs of genetic pollution, food safety, and hazards [48].

Another way in which food industry makes it increasingly difficult for consumers to live a good life with food is that in using normative expressions like consumer free choice, it tries to expel as much as possible consumers out of the kitchen by providing processed food. For IBI, convenience food (fast food) and the convenience consumer are the standards. The portions of processed food - from cakes to ready meals - are way larger than they were in the nineteenths, with lots of sugar, salt and fat [33] [38] [39]. A study by the British Heart Foundation from 2013 [51] claims that supersize portions of food sold by some leading supermarkets are 'out of control' and harming people, fuelling an obesity crisis and contributing to heart disease. Industry and its shareholders strive for profits in selling more and more, including bigger portions with as cheap ingredients as possible [22a]. Marketers and nutritional scientists construct, in their textbooks, the consumer into a convenience shopper who no longer wants to spend time in the kitchen. In leaving food preparation to the food industry, it is supposed that she or he, in fact, entrust the food industry to develop and sell ready-made foodstuffs with additives and other chemicals [33]. These constructions of the consumer as either lazy or irrational are often barriers for a fruitful understanding of the motives of consumers [22]. As a consequence, differentiation of food purchasing through labeling and certification allows at least some consumers to express ethical concerns through their purchasing choices. Alternatively, many politicians and scientists perceive consumers' opinions, in particular with respect to genetically modified organisms (GM) and additives as irrational and emotional.

The regime of intensive or industrialized agriculture with high (artificial) inputs and high outputs are seen by many as unsustainable; it decreases (agro-) biodiversity, it increases erosion, it is animal unfriendly and it depletes scarce resources.

Indeed, this system doesn't have good scores on the six ethical criteria: Can the style reduce hunger, poverty and malnutrition? Is it sustainable? Is it animal welfare friendly? Is it fair and just to farmers and others? Does it stimulate rural liveability? Is it consumer friendly: does it increase or decrease the gap between production and consumption and does it connect positively with urban areas?

Because of these concerns, business as usual in the sense of continuing the current dominant agricultural and food regime is ethically seen not acceptable. Some agronomists believe that only new sciences like genomics or biotechnology can contribute in alleviating these problems [23]; but the complexity of the issues and the multi functionality of agriculture and food prevent solutions on the basis of one branch of science. Moreover, the claims of agro- and nutrigenomics are nowadays by many perceived as exaggerated [24].

More important than these efforts is setting targets for radical reform which the cooperation of scientists, farmers and consumers step by step can realize. I am thinking firstly of halving hunger and malnutrition and halving chemicals in ten years, with exclusion from markets for companies that didn't contribute to these targets. Secondly, I recommend stop on more milk from cows, more eggs from chickens, more meat from livestock and giving them the five freedoms in ten years. Thirdly, it is worthwhile to think about a stop on agricultural investments in the South for products in the North, and a ban on dumping of agricultural products in the South. Fourthly, I am recommending the shrinking of food chains and the obligation of supermarkets to sell local food not less than thirty percent of their products. Fifthly, one should oblige corporations to publish yearly ethical reports with targets, to appoint citizen juries that monitor these reports and targets and to fine companies that not do reach their targets. Sixthly, one should channel all private money streams for public research institutes into several independent committees that distribute the money according to a substantial evaluation of project plans, etc, etc, etc. 


\subsection{Food from Somewhere: Agro-Ecology, Farm to Table, Agrarianism, Glocalism}

The majority of farmers live in the South (approximately 1.5 billion people) and more than $85 \%$ are poor, often not owning their own land. They are involved in a different agro-food regime, producing for local or regional markets. Being poor, pesticides and fertilizers are used in small amounts [12]. Many of these farmers have learned to improve the soil with organic material, and intercropping (agro-ecology and agroforestry). Two more sophisticated methods, applying principles of scientific trial and error, are agro-ecology [44] [45] and the system of rice intensification (SRI), applied also to wheat and corn [46] [47]. These two methods can increase current yields with a factor two or more, with less environmental and economic costs than further intensification by chemicals such as IBI prescribes. Tittonell [21] argues convincingly that '... most importantly, food will be produced where it is urgently needed, and where the surpluses can generate extra income for poor rural households.' [29]. It is important to emphasize that this movement has not much to do with a so-called romanticism of some Western consumers and is not anti-science. Farmers in developing countries started movements like Via Campesina; they are proud on their work and are eager to learn from others which can strengthen their food sovereignty. According to this regime, the cooperation of "external science", indigenous technological development, and cash-crop orientation can increase harvest quality and quantity, partly for the market and partly for the subsistence of farmers. For example in the Kilombero Valley, Tanzania, rice is a cash crop as well as a subsistence crop; the subsistence crop serves as an income generator for technological investments in the cash crop. The two methods connect soil and table; they imply a route toward food sovereignty and local employment different from that of the cheapest price and the highest externalities.

These methods also have found a lot of interest in the rich West. Food should come from somewhere, from places that can be located and are by preference near. As a matter of fact, not all products need to come from nearby, and not every country can produce citrus fruits, coffee or banana. Depending on the area, and the preference of citizen/consumers, some products can come from far. Therefore, this connection is often called glocal, mostly local, and when necessary, global.

\subsection{Food Democracy from Soil to Table and Table to Soil: Prospects}

In the earlier section I have argued that with regard to the current dominant food regime, consumers and farmers have no control over the priorities what to produce and to invest in and therefore no control over the relation of society with nature and agriculture. This lack of control and involvement makes of citizen-consumers a debilitating force. Democracy cannot be realized when citizens are fully dependent on industrial food production. For citizenship to be realized it is not only necessary to maintain positively public conditions like health, education, and mass media that offer interesting facts about important social issues (and not only about careers of soccer players or film stars) [26]. Citizenship cannot thrive on the basis of a regime of an anonymous and distantiated agro-food system that increases the gap between producers and consumers due to the economic value of profits and comparative advantage [27]. Free from democratic input and motivation, this regime is stimulating individualistic greed, creating a poor and malnourished underclass and is more and more insensitive to judgments, worldviews, fears and emotions from its end-users.

My conclusion on the basis of the evaluation of current evidence is that the dominant IBI regime is to be changed to an ethical acceptable regime. Due to the uncertainties, complexities of agriculture and food production but also to some of the recent innovations in this regime, it is too early to give a definitive conclusion, and I cannot give a total negative evaluation. The issue is not, do we need IBI, or the agro-food regime, but in what form and measure. Therefore, the question of either reforming the current dominant regime (IBI) or starting alternatives is not an important issue; both are necessary. The pressing issue is to organize the fair representation of food and farming styles, which means how to deal with the different food and farming styles in a constructive way that gives opportunities to all in a fair and just process [41, p. 228]. Food democracy from table to soil and from soil to table starts with the idea that 'there may not indeed exist any identifiable perfectly just social arrangement on which impartial agreement would emerge' [41, p. 15]. Food and farming styles will differ, and it is meaningless to try to overcome these differences by an appeal on mostly controversial facts or some other rock-bottom. Deliberation about deeply felt frictions between styles and cooperation are more fruitful strategies. 
With respect to food production and consumption, it means that the deliberative approach cannot stand on its own. Sure, it needs tools like scenario building, and looking for positive matches between technologies and deliberative openings, and deliberations about uncertainties, fears and new ideas and opinions [28]. But more is necessary. Cooperation, working together and collective action with regard to food give meanings and experiences to democratic control and formation of beliefs. In bringing together eating, cooking and farming personal and social identity activities are affirmed, maintained and renovated. It is this connection of food production, of the soil, with the life world where philosophy can make a difference, because it shows that what is made according to current IBI definition of efficiency is not the best for having a good life. Cooking and eating are not simply activities that keep our day-today life going but they are identity-achieving activities: they contribute to what we are and how we appreciate ourselves.

Deliberation about food is only fruitful when participants do something where food comes from: cooking, farming, producing some food or organizing some process or product. This practical knowledge is an inspirational basis of being able to remain connected and to acquire new insights and to put forward fruitful opinions. Deliberations on food enhance their quality when fed by embodied knowledge. This knowledge improves when it is daily exercised and it deteriorates when not exercised, just like a bodily condition needs exercises to remain in good shape. Shared internalized norms are helpful, but they are not necessary, cooperation and exercise does.

\section{Conclusion}

The current regimes of agricultural and food production, the dominant intensive bio-industry (IBI), or the 'productionist paradigm' and the agro-ecological / alternative regime have their pros and cons. The productionist paradigm of agriculture and food is dominant and aims at high inputs and high outputs. Although this paradigm has succeeded in feeding billions of people, it also produces huge problems, which make it unsustainable and socially not fair. Nevertheless, this approach is dominant today. In order to produce good food for enough people, a radical reform of this regime is ethically seen necessary. But more important, we need a pluralist approach that take seriously the best practices of small and medium farmers and innovators and the pleasure and social interaction that food for consumers can bring. Alternatives as agro-ecology propose as short links as possible between farm and table and represent a much broader approach that covers localized food production and consumption, and aims at food from somewhere. In often elaborate but nearby networks, without as little long distanced production elements as possible, food is produced and prepared as near as possible to the table.

Food democracy, dealing with pluralism in a fair way and fair representation of farming and food styles requires that the Glocal and agro-ecological movement deserves a lot more scientific, social and political attention than now is the case, and it is to be hoped that that movement will grow the next decades. This will only happen when the farm also listens to the table, and considers seriously the various food preferences of people living in urban areas. Life sciences have a responsible task in improving these agricultural and food practices by taking into account the complexities not by selecting only a few variables. Natural scientists and social science should work together to find how a just and fair match between agriculture and society can be established. This is in particular necessary given the often naif and not validated social intuitions about consumers for instance that they are convenience or cheap food driven.

\section{References}

1. Altieri, M. A., Fernando R.Funes-Monzote \& Paulo Petersen, 2011, Agroecologically efficient agricultural systems for smallholder farmers: contributions to food sovereignty -Agronomy for Sustainable Development, Published online 14 December 2011, DOI 10.1007/s13593-011-0065-6

2. Berne Declaration 2013, http://www.evb.ch/en/p9451.html

3. British Hearth Foundation, 2013, Portion Distortion. How much are we really eating? London: BHF

4. Cochrane, W., 1993, The Development of American Agriculture: A Historical Analysis, Univ. of Minnesota Press

5. Coff, Ch., Barling, D., Korthals, M. (Eds.), 2009, Ethical Traceability in Communicating Food, Dordrecht: Springer 
6. Critser, G. (2003), Fat Land: How Americans Became the Fattest People in the World, Boston: Mariner Books

7. De Schutter, O., (2010), Food Commodities Speculation and Food Prices Crisis, Briefing note 02, United Nations

8. De Schutter, O., 2013, Interim report of the Special Rapporteur on the right to food, http://www.unhchr.ch/tbs/doc.nsf/0/3d02758c707031d58025677f003b73b9

9. Driessen, C., and M. Korthals, 2012, Pig towers and in vitro meat: Disclosing Moral Worlds by Design, Social Studies of Science, 42, 6, 797-820

10.Eide, A. et al (eds.), 1984, Food as a Human Right, Tokyo, Paris: United Nations University

11.Ewers, R., Jörn P. W., Scharlemann, et al, 2009, Do increases in agricultural yield spare land for nature? Global Change Biology, Volume 15, Issue 7, pages 1716-1726.

12.FAO (2010). The State of Food Insecurity in the World Addressing food insecurity in protracted crises. http://www.fao.org/docrep/013/i1683e/i1683e.pdf (accessed 27/08/2012)

13.Fresco, L., 2013, Hamburgers in het Paradijs, Amsterdam: Bakker.

14.Gaskell, G., et al. 2010. 'Europeans and Biotechnology in 2010: Winds of Change?'

15.Eurobarometer 73.1 on the Life Sciences and Biotechnology. Brussels: European Commission. http://ec.europa.eu/public_opinion/.

16.Glover, D., 2010, Is Bt Cotton a Pro-Poor Technology? A Review and Critique of the Empirical Record. Journal of Agrarian Change, 10: 482-509. doi: 10.1111/j.1471-0366.2010.00283.x

17.Gottlieb, R., A. Joshi (eds.), 2010, Food Justice, Cambridge: MIT

18.Grievink, F-W., 2013, Erasmus Food Management Institute, efmi.nl

19.Haen, D., 2013, The Paradox of E-Numbers: Ethical, Aesthetic, and Cultural Concerns in the Dutch Discourse on Food Additives, J Agric Environ Ethics

20.Harrison-Dunn, Annie-Rose, 03-Feb-2014, Sustainability review: Huge growth of sustainable companies but developed nations dominate, Food Navigator

21.Herring, R. J. (ed.), 2014, Handbook on Food, Politics and Society, Oxford University Press

22.Holt-Gimenez, E., Raj Patel, 2009, Food Rebellions: Crisis and the Hunger for Justice, Cape Town: Pambazuku Press

23.IAASTD, 2009, http://www.agassessment.org/

24.Korthals, M., 2004, Before Dinner, Dordrecht: Springer

25.Korthals, M. (Ed.), 2011, Genomics, Obesity and the Struggle over Responsibilities, Dordrecht: Springer

26.Korthals, M., 2012, Ethische aanvaardbaarheid van Nudging voor Overheid en Bedrijfsleven, WUR, pp. 45, Essay in opdracht van Ministerie van Economische Zaken, http:wu.academia.edu/michielkorthals.

27.Korthals, M., 2014,The food we eat: the right to be informed and the duty to inform, in: R. Chadwick, Mairi Levitt and Darren Shickle (Eds), The Right to Know and the Right not to Know, Cambridge: Cambridge University Press

28.Lang, T. and M. Heasman, 2004, Food Wars, London: Earthscan Books.

29.Liberti, S., 2013, Land Grabbing. Journeys in the new colonialism, London: Verso Millstone, E., and T. Lang, 2008, The Atlas of Food, London: Earthscan

30.Moss, R., 2013, Fat, Sugar, Salt, London: Allen Nestle, M., 2002, Food Politics: How food industry influences nutrition and health, Berkeley: University of California Press.

31. O’Neill, J., A. Holland, and A. Light, 2008, Environmental Values, London: Routledge

32. Oxfam Novib, 2013, Behind the Brands, behindthebrands.org

33.Palmer, C., 2011. Animal Ethics in Context. Columbia University Press.

34.Patel, R., 2008, Stuffed and Starved: The Hidden Battle for the World Food System, London: HarperCollins

35.Pfeiffer, Dale Allen, 2006, Eating Fossil Fuels: Oil, Food and the Coming Crisis in Agriculture. Gabriola Island, BC, Canada: New Society Books.

36.Pimentel, D., 2005, Environmental and economic costs of the application of pesticides primarily in the United States, Environment, Development and Sustainability, 7: 229-252

37.Pinstrup-Andersen, P., and P. Sandoe (Eds.), 2007, Ethics, Hunger and Globalization, Dordrecht: Springer

38.Roberts, R., 2008, The End of Food. London: Bloomsbury

39.Schlosser, E., 2001, Fast Food Nation. New York: Perennial

40.Sen, A., 2009, The concept of Justice, London: Lane

41.Standage, T., 2009, An Edible History of Humanity, New York: Walker and Co. 
42.Stevens, C. J., Dise, N. B. Mountford, J. O. Gowing, 2004, Impact of nitrogen disposition on the species richness of grasslands, Science 303 1879-1875

43.Stoop, W. A., N. Uphoff and A. Kassam (2002). A review of agricultural research issues raised by the system of rice intensification (SRI) from Madagascar: Opportunities for improving farming systems for resourcepoor farmers. Agricultural Systems, 71, 249-274.

44.Tansey, G., 2008, The Future Control of Food: A Guide to International Negotiations and Rules on Intellectual Property, Biodiversity and Food Security, London: Earthscan Techniek in Nederland, TIN.nl.

45.Thaler, R., C. Sunstein, 2009, Nudge: improving decisions about health, wealth and happiness, London: Penguin.

46.Tittonell, P., 2013, Farming Systems Ecology. Towards ecological intensification of world agriculture, Wageningen: WU

47.Tomich, Th, et al., 2011, Agroecology: A Review from a Global-Change Perspective, Annual Review of Environment and Resources, Vol. 36: 193-222

48.UNCTAD, 2013, Trade and Environment Review 2013, A Wake up call. http://unctad.org/en/PublicationsLibrary/ditcted2012d3_en.pdf

49.Uphoff, N., I. Anas, O.P. Rupela, A.K. Thakur and T. M. Thiyagarajan (2009). Learning about positive plantmicrobial interactions from the System of Rice Intensification (SRI). Aspects of Applied Biology, 98.

50.Van Ittersum, M., et al., 2008. Integrated assessment of agricultural systems - A component-based framework for the European Union (SEAMLESS). Agricultural Systems, 96, 150-165.

51.Van Swaay CAM, 2008, Butterfly ring in Europe: Methods, applications and perspectives, Biodiversity and Conservation, 17, 3455-3469.

52.Wallace, H., 2010, Bioscience for Life? Who decides what research is done in health and agriculture? London: Genewatch

53.World Bank, 2013, World Development Report, Washington: World Bank.

54.Wrangham, R. 2009. Catching Fire. How Cooking Made Us Human. London: Profile.

\section{Website (accessed January 2017)}

http://www.project-syndicate.org/commentary/agricultural-investment-or-third-world-land-grab-bypeter-singer

1. See for this criterion of fairness: John Rawls' Theory of Justice, Cambridge, allowing, as under the condition of the veil of ignorance, competition and unequal distribution of resources of as long as the losers are as well off as they can; Michiel Korthals, Before Dinner, 2006, Chapter 5.

2. For an elaboration of the first four of these criteria, see Korthals' Before Dinner, 2006, Chapter 7 and 8

3. Eric Holt-Gimenez and Raj Patel, 2009, Food Rebellions: Crisis and the Hunger for Justice, Cape Town: Pambazuku Press; Gailus, M., Volkmann, H., (eds), 1990, Der Kampf um das tägliche Brot. Nahrungsmangel, Versorgungspolitik und Protests 1770-1990, Opladen; Techniek in Nederland, TIN, p. 330.

4. Michael Pollan in Cooked, 2013, gives some nice examples of how food items represent dimensions of the meanings of life; for instance, cheese is all about the dark side of life, p. 360.

5. Instead of an academic reference, a reference to Salman Rushdie, who in his nice book Shalimar the Clown (2009) describes how Bulbul, a Sufi saint, converts Rinchin, Lord of Ladehk, to Islam and so makes Islam one of the many religions of this small landlocked mountain state where a feast has at least 36 courses. Unfortunately later religious disputes degenerated in religious radicalization; this turn of events shows the vulnerability of meals and the need to maintain and to invest time and energy in meals.

6. Fresco 2013, Hamburgers in het Paradijs, Amsterdam: Bakker; Laudan, R., 2013, Cuisine and Empire. Cooking in World History. University of California Press: 'If our vision of the way to have better food is to have less processing, more natural food, more home cooking, and more local food, we will cut ourselves off from the most likely hope for better in the future.'

7. Busch, L., 2011, Standards: Recipes for Reality, Cambridge: MIT Press: 'Even as such forms of trust are necessary in some settings, living in a world in which all forms of trust were monological, I submit, would be 
nearly intolerable; it would replace the richness of dialogue and experience with a focus on surface characteristics. Moreover, it would require constant auditing and certification of everything and everyone.'.

8. According to Korthals, M., 2012, Ethische aanvaardbaarheid van Nudging voor Overheid en Bedrijfsleven, WUR, pp. 45, Essay in opdracht van Ministerie van Economische Zaken, http:wu.academia.edu/michielkorthals, it is not necessary to search continuingly for self-discovery for to become an autonomous person.

9. Thaler, R., C. Sunstein, 2009, Nudge: improving decisions about health, wealth and happiness, London: Penguin. Therefore choice architecture and nudging are important devices

10.www.farmland.org/programs/localfood/documents/foodmiles_Leopold_IA.pdf reports that ingredients for strawberry yoghurt, milk, sugar, and strawberries have travelled at least 2,216 miles.

11. This type of advantage, only directed to profit in terms of money, determines also what is seen as 'efficient'; many think that free trade can effectuate it. Adam Smith, stressed this in his Wealth of Nations, p. 72, and followed Mandeville in this (The Fable of the Bees, pt. ii. 335-6, ed. Kaye ii.284): "'Man', as I have hinted before, naturally loves to imitate what he sees others do, which is the reason that savage People all do the same thing: This hinders them from meliorating their Condition, though they are always wishing for it: But if one will wholly apply himself to the making of Bows and Arrows, whilst another provides Food, a third builds Huts, a fourth makes Garments, and a fifth Utensils, they do not only become useful to one another, but the Callings and Employments themselves will in the same Number of Years receive much greater Improvements, than if all had been promiscously follow'd by every one of the Five."

12. What belongs to IBI and what not is not easy to say; there is a tendency to let the Intensive Bio-Industry cover all the good things and to put the negative aspect on the side of other societal processes, or vice versa. I have chosen here for a quite broad definition, because the immense power of this regime can only be maintained due to its strong connections with and stimulating influence on other social developments.

13. Connected with the first issue is that of malnutrition. Many people in the poorer areas having often enough to eat suffer from severe diseases due to lack of necessary micronutrients (vitamins, minerals), such as stunted growth, blindness, and concentration problems. In the richer areas, there are also problems of malnutrition due to long-term unhealthy effects of the current food regime, including obesity (Critser 2003), cardiovascular diseases, type 2 diabetes, and various types of cancer (Lang and Heasman 2004, Food Wars, London: Earthscan Books; Korthals, M. (Ed.), 2011, Genomics, Obesity and the Struggle over Responsibilities, Dordrecht: Springer.

14.Carolan, M. 2011 The Real Cost of Cheap Food. Abingdon: Earthscan; In the Netherlands the use of chemicals per hectare (pesticides, herbicides, fungicides and nematicides) is still thrice as large as in Germany, and four to five times larger than in Denmark (LEI 2013, p. 94 and TIN, 5, p. 224; World Resources Institute. Aggregates compiled by NationMaster. Retrieved March 2014, http://www.nationmaster.com/country-info/stats/ Agriculture/Pesticide-use. Dutch agriculture has been compared with the Olympic champion Usain Bolt; a comparison with cyclist Lance Armstrong is more apt.

15.Titonell, 2013: 'Due to poor practices in harvesting, storage and transportation, as well as market and consumer wastage, it is estimated that 30 to $50 \%$ (or $1.2-2$ billion tonnes) of all food produced never reaches the human stomach (Gustavsson et al., 2011; IMECHE, 2013). Wastes may occur post harvesting, post processing, and post consumption. In SE Asia, for example, postharvest losses of rice can range from 40 to $80 \%$. In India, 21 million tonnes of wheat are wasted every year due to poor storage and distribution systems. To assess the order of magnitude of such a figure, it suffices to compare it against the total annual production of wheat in The Netherlands, of 1.2 million tonnes per year. Every year, India loses the equivalent of 18 times the total production of all Dutch wheat farmers considered together.' Malnutrition is often not due to lack of sufficient micronutrients but these post-harvest losses.

16. That is one of the reasons why UNCTAD in Trade and Environment 2013, A Wake up call, pleads for: 'A rapid and significant shift from conventional and monoculture based and high-external-input dependent industrial system towards mosaics of sustainable production systems that also considerable improve the productivity of small scale farmers.'

17.Jeroen Visscher, ISA Senior Geneticist, of Hendrix Genetics promises for example "Our mission to breed for 500 first quality eggs without molting, is expected to be reached for commercial egg producers by 2020", www.hendrix-genetics.nl.

18.Grievink 2013; UNCTAD 2013; IAASTD 2009; Annie-Rose Harrison-Dunn, 03-Feb-2014, Sustainability review: Huge growth of sustainable companies but developed nations dominate, Food Navigator; the article presents a 
review of the International Institute for Sustainable Development (IISD) that in particular larger firms are entering the market of sustainable foods, but putting small and integer firms at a disadvantage. Still, food industry stays behind these small firms, as Oxfam Novib noticed in her Behind the Brands (2013). 'The ten biggest food companies still earn the most with drinks, breakfast cereals, chips and bars loaded with sugar and unhealthy fat. Those 10 companies in the middle are now the biggest food and beverage companies in the world. Together, they generate revenues of more than $\$ 1.1$ billion a day. They also employ millions of people in poor countries, directly and indirectly, to grow and produce their products. Because of their global reach and influence, these companies could play a big role in reducing poverty, hunger, and inequality. But right now, they're not doing enough.' Oxfam spent 18 months looking closely at how the "big 10" say they do business. 'Then we created an easy-to-use scorecard - a "behind the brands" look-comparing and contrasting their policies and commitments. We discovered that all 10 need to do a whole lot more to support farmers, communities, and our planet.'

19.http://www.worldwatch.org/node/810: The "ecological footprints" range from the 9.7 hectares claimed by the average American to the 0.47 hectares used by the average Mozambican.

20.Ten percent of the world population enjoys ninety percent of the resources in making drugs, Drugs for Neglected Diseases Working Group. 2001, Fatal Imbalance, p.10, http://www.doctorswithoutborders.org/publications/ reports/2001/fatal_imbalance_short.pdf

21.Wallace, H., 2010, Bioscience for Life? Who decides what research is done in health and agriculture? London: Genewatch; http://www.project-syndicate.org/commentary/agricultural-investment-or-third-world-land-grab-bypeter-singer; only 6 per cent..: Nienke M. Beintema and Gert-Jan Stads, Measuring Agricultural Research Investments: A Revised Global Picture, 2008, available from http://www.asti.cgiar.org/pdf/global_revision.pdf.

22.Efficiency is often measured according to one dimension, like yields per hectare, or yields per animal (eggs, meat) or yields per labor hour. However, what is left out are the contexts and external costs, like animal welfare, environmental (current and future) costs, like resource depletion, adaption and accommodation to climate change, loss of biodiversity, health costs (use of pesticides) etc. Tittonell, P., 2013, Farming Systems Ecology. Towards ecological intensification of world agriculture, Wageningen: WU

23.It is silly to read how captains of industry repudiate their responsibility: NRC 10-08-2013, Hessel de Jong, CEO Coca-Cola Benelux, "we do not cause obesity. NRC, 31-1-04 'the proposition of Anthony Burgmans (CEO Unilever till 2012): 'a Magnum fits in a good diet'.

24. There is evidence that food industry started and stimulated the trend of convenience, Shapiro for examples shows that the industrialization of eating, i,e, the move out of the kitchen, is a supply driven phenomenon. Shapiro, L. 2004, Something from the oven. Reinventing Dinner in 1950s America, New York: Viking; also Pollan, Cooked, 2013, p. 185. Haen (2013) shows that in many academic handbooks about food additives convenience is supposed to be the standard of rational eating, together with micro-wave and other material devices.

25.Borlaug, N. E. (2000). Ending world hunger: The promise of biotechnology and the threat of antiscience zealotry. Plant Physiology, 124, 487-490

26.Ford Denison, R., 2012, Darwinian Agriculture, Princeton University Press, p. 150: 'The likely near term benefits of biotechnology and genomics have been exaggerated.' Scientists are often in the emotional overdrive when talking about the future outcome of molecular biology research, like, promising that hunger will be something of the past.

27.Examples can be found on www.farmtotablecoop.com. In the Netherlands: www.varkenshuis.nl; www.rotterdamseoogst.nl; growingpower.org; transfarmers.nl.

28.John Dewey develops in his The Public and its problems a theory of media still relevant for today's media.

29.Against Axel Honneth, Das Recht der Freiheit, Frankfurt: Suhrkamp, p. 546.

30.These are the main ethical tools that Dewey in his The Public and its problems recommends and which Habermas has updated

31.De Schutter, O., (2010), Food Commodities Speculation and Food Prices Crisis, Briefing note 02, United Nations; De Schutter, O., 2013, Interim report of the Special Rapporteur on the right to food, http://www.unhchr.ch/tbs/doc.nsf/0/3d02758c707031d58025677f003b73b9.

32.Palmer, C., 2011. Animal Ethics in Context. Columbia University Press.. 
33.Korthals, M., 2014,The food we eat: the right to be informed and the duty to inform, in: R. Chadwick, Mairi Levitt and Darren Shickle (Eds), The Right to Know and the Right not to Know, Cambridge: Cambridge University Press

34.Wrangham, R. 2009. Catching Fire. How Cooking Made Us Human. London: Profile.

35.Moss, R., 2013, Fat, Sugar, Salt, London: Allen

36.Eide, A. et al (eds.), 1984, Food as a Human Right, Tokyo, Paris: United Nations University

37.Korthals, M. (Ed.), 2011, Genomics, Obesity and the Struggle over Responsibilities, Dordrecht: Springer.

38.Driessen, C., and M. Korthals, 2012, Pig towers and in vitro meat: Disclosing Moral Worlds by Design, Social Studies of Science, 42, 6, 797-820.

39.Coff, Ch., Barling, D., Korthals, M. (Eds.), 2009, Ethical Traceability in Communicating Food, Dordrecht: Springer.

40.Schlosser, E., 2001, Fast Food Nation. New York: Perennial

41.Nestle, M., 2002, Food Politics: How food industry influences nutrition and health, Berkeley: University of California Press.

42.Pinstrup-Andersen, P., and P. Sandoe (Eds.), 2007, Ethics, Hunger and Globalization, Dordrecht: Springer

43.Sen, A., 2009, The concept of Justice, London: Lane.

44.Roberts, R., 2008, The End of Food. London: Bloomsbury

45.Tansey, G., 2008, The Future Control of Food: A Guide to International Negotiations and Rules on Intellectual Property, Biodiversity and Food Security, London: Earthscan

46.Altieri, M. A., Fernando R.Funes-Monzote \& Paulo Petersen, 2011, Agroecologically efficient agricultural systems for smallholder farmers: contributions to food sovereignty -Agronomy for Sustainable Development, Published online 14 December 2011, DOI 10.1007/s13593-011-0065-6

47.Tomich, Th, et al., 2011, Agroecology: A Review from a Global-Change Perspective, Annual Review of Environment and Resources, Vol. 36: 193-222

48.Stoop, W. A., N. Uphoff and A. Kassam (2002). A review of agricultural research issues raised by the system of rice intensification (SRI) from Madagascar: Opportunities for improving farming systems for resourcepoor farmers. Agricultural Systems, 71, 249-274.

49.Uphoff, N., I. Anas, O.P. Rupela, A.K. Thakur and T. M. Thiyagarajan (2009). Learning about positive plantmicrobial interactions from the System of Rice Intensification (SRI). Aspects of Applied Biology, 98.

50.Thompson, P. 2007, Food Biotechnology in Ethical Perspective, Dordrecht: Springer.

51.Gaskell, G., et al. 2010. 'Europeans and Biotechnology in 2010: Winds of Change?' Eurobarometer 73.1 on the Life Sciences and Biotechnology. Brussels: European Commission. http://ec.europa.eu/public_opinion/.

52.Cochrane, W., 1993, The Development of American Agriculture: A Historical Analysis, Univ. of Minnesota Press 53.British Hearth Foundation, 2013, Portion Distortion. How much are we really eating? London: BHF

54.Glover, D., 2010, Is Bt Cotton a Pro-Poor Technology? A Review and Critique of the Empirical Record. Journal of Agrarian Change, 10: 482-509. doi: 10.1111/j.1471-0366.2010.00283.x

55.Pimentel, D., 2005, Environmental and economic costs of the application of pesticides primarily in the United States, Environment, Development and Sustainability, 7: 229-252

56.Pfeiffer, Dale Allen, 2006, Eating Fossil Fuels: Oil, Food and the Coming Crisis in Agriculture. Gabriola Island, BC, Canada: New Society Books.

57.Standage, T., 2009, An Edible History of Humanity, New York: Walker and Co

58.Berne Declaration 2013, http://www.evb.ch/en/p9451.html.

59.O'Neill, J., A. Holland, and A. Light, 2008, Environmental Values, London: Routledge.

60.Liberti, S., 2013, Land Grabbing. Journeys in the new colonialism, London: Verso 